\title{
Host site of activity and cytological effects of histone-like proteins on the parasitic dinoflagellate Amyloodinium ocellatum
}

\author{
Edward J. Noga*, Zhiqin Fan, Umaporn Silphaduang \\ Department of Clinical Sciences, College of Veterinary Medicine, North Carolina State University, 4700 Hillsborough Street, \\ Raleigh, North Carolina 27606, USA
}

\begin{abstract}
Histone-like proteins (HLPs) are broad-spectrum, endogenously produced antibiotics which we have isolated from tissues of rainbow trout Oncorhynchus mykiss and hybrid striped bass (Morone saxatilis male $\times M$. chrysops female). Here, we show that HLP-1, which has high sequence homology to histone $\mathrm{H} 2 \mathrm{~B}$, equally inhibited both young and mature trophonts of the important ectoparasite Amyloodinium ocellatum. In addition to direct killing of Amyloodinium trophonts, there was evidence that HLP-1 from both rainbow trout and hybrid striped bass caused severe developmental abnormalities, including delayed development, in both the parasitic trophont stage as well as the reproductive tomont stage. The deleterious effects of HLP-1 also were manifested in what appeared to be 'delayed mortality', where parasites of normal appearance would die later in development. Similar serious damage was also seen with calf histone H2B and the unrelated peptide antibiotic magainin 2. A comparison of the antibiotic activity in mucus versus epidermis compartments of the skin of hybrid striped bass suggested that the majority of antibiotic (including HLP-1) activity resided in the epidermis, although some activity was present in the mucus. These data suggest that normal, nonimmune fish skin contains potent defenses against protozoan ectoparasites and that the effects of these defenses may extend beyond their transient interactions with the parasites, which has important implications for this host-parasite relationship.
\end{abstract}

KEY WORDS: Histone-like proteins $\cdot$ Innate immunity $\cdot$ Fish

\section{INTRODUCTION}

Protozoan ectoparasites cause serious losses in virtually all cultured marine and freshwater fish (Woo 1995). Among the most important is the dinoflagellate Amyloodinium ocellatum, which causes serious epidemics in warmwater mariculture worldwide (Noga \& Levy 1995). In Amyloodinium's life cycle, the infective stage (dinospore) attaches to the host, forming the feeding (trophont) stage. After feeding, the trophont detaches from the host cell, falls off the host, and forms the reproductive stage (tomont), which produces

*Email: ed_noga@ncsu.edu dinospores. A. ocellatum is the only protozoan ectoparasite which can be propagated in vitro, and is a useful model for closely examining the effects of immune components on ectoparasite survival in a system which is very similar to that of the in vivo host (Noga 1987, Smith et al. 1993, Oestmann \& Lewis 1996, Cobb et al. 1998).

In recent years, host-produced, polypeptide antibiotics have become recognized as important components of innate immunity in many organisms (see Robinette et al. 1998, Schroder 1999, Mitta et al. 2000, Tossi et al. 2000, Zasloff 2002, for recent reviews). We have recently isolated potent, broad-spectrum polypeptide antibiotics from channel catfish Ictalurus punctatus (Robinette et al. 1998). These antibiotics, which we 
have named histone-like proteins (HLPs), are closely related, if not identical, to histone H2B (HLP-1) and histone H1 (HLP-2). Histones are well-known components of the nucleosome. However, we have discovered that, at what appears to be well within physiologically available concentrations, these polypeptides are highly lethal to both bacteria and water molds (Robinette et al. 1998). We have also recently shown that HLPs isolated from hybrid striped bass (Morone saxatilis male $\times M$. chrysops female) and from rainbow trout Oncorhynchus mykiss have potent activity against Amyloodinium ocellatum (Noga et al. 2001). The purpose of this paper was to determine the site on the skin (i.e. mucus vs epidermis) where these antimicrobial proteins were most likely to function against A. ocellatum, the effect of parasite maturity on its susceptibility to HLPs, and the morphological effects of hybrid striped bass and rainbow trout HLPs on A. ocellatum development.

\section{MATERIALS AND METHODS}

Antimicrobial activity under different collection conditions. Initial studies in our laboratory have shown that skin extracts from hybrid striped bass (Morone saxatilis male $\times M$. chrysops female) and from rainbow trout Oncorhynchus mykiss have significant antibacterial activity (Noga et al. 2001). To determine whether this activity resided mainly in the mucus or in the epidermis, we collected skin mucus from anesthetized fish by gently scraping the body surface. Neat (undiluted) mucus was collected by gently moving a glass $0.5 \mathrm{ml}$ pipette along the flank while holding the fish in a vertical position and aspirating the sample with another sterile pipette (first neat mucus sample, M1N; this sample was relatively thin); a second sample was then collected from the much thicker mucus that was released after the first sample had been collected (second neat mucus sample, M2N). This stroking motion caused the mucus to 'pile up'; both M1N and M2N were then collected by gently aspirating with a sterile pipette. Once most of the mucus had been removed, we then collected epidermis by scraping the body surface with a metal spatula. Mucus and epidermis samples were immediately examined under a phase contrast microscope (Nikon Diaphot) for the presence of cells.

The epidermis samples were split into 3 equal volumes and homogenized in an Eppendorf tube with a Teflon homogenizer using 3 volumes of either $1 \%$ acetic acid (preceded by boiling for $5 \mathrm{~min}$ ), distilleddeionized water, or $50 \mathrm{mM}$ tris buffer $(\mathrm{pH}$ 7.2). All samples were briefly stored on ice until testing for antibacterial activity (see below).
The antibacterial activity of various samples (M1N, M2N, epidermis extracts) was immediately assessed in a radial diffusion assay (Robinette et al. 1998) in which a specific volume $(3 \mu \mathrm{l})$ of sample was pipetted into a well of an agarose plate with a suspension of Escherichia coli D31. After overnight incubation at $37^{\circ} \mathrm{C}$, the clearing zone diameter for each of the samples was compared. The units of antibacterial activity were calculated using a standard curve of a purified antibiotic standard. Briefly, units of antibacterial activity were determined from a standard curve generated from a serial dilution of pure hybrid striped bass HLP1 (HSB HLP-1) in the radial diffusion assay. This HSB HLP-1 curve was generated by log-transforming the clearing zone diameters to create a linear curve. Clearing zone diameters measured in each sample were also log-transformed and their values in log units were then determined from the HLP-1 standard curve. Values were then converted to arithmetic units of activity (and HLP-1 $\mu \mathrm{g} \mathrm{ml}^{-1}$ equivalents).

Epidermis samples were also electrophoresed on acid urea-polyacrylamide gels (AU-PAGE) (Harwig et al. 1993) to determine the presence of putative HLPs in neat mucus and under different epithelium extraction conditions. Separations were performed using the Mini-Protean II (BioRad) electrophoresis system according to manufacturer's instructions.

Purification of antibiotics for testing. HLP was purified from clinically normal rainbow trout and hybrid striped bass using methods described previously (Robinette et al. 1998, Noga et al. 2001). Briefly, gill (hybrid striped bass) or spleen (rainbow trout) was extracted by boiling in dilute acetic acid and then preparing a tissue homogenate. After partial purification of the HLPs by strong acid precipitation to remove contaminating proteins, final purification was achieved by separation via reverse-phase, high pressure liquid chromatography (RP-HPLC). Since HLP-1 is the HLP with the most potent anti- $A$. ocellatum activity (Noga et al. 2001), our studies were focused on this antibiotic.

The purity of rainbow trout HLP-1 (RBT HLP-1) and HSB HLP-1 isolated via RP-HPLC was assessed by sodium dodecyl sulfate-polyacrylamide gel electrophoresis (SDS-PAGE) (Laemmli 1970) using the Mini-Protean II electrophoresis system according to manufacturer's instructions. The purity of HLP-1 was $>95 \%$ as assessed by SDS-PAGE.

Anti-Amyloodinium assays. The effects of RBT HLP1 or HSB HLP-1 on A. ocellatum was examined using our standard in vitro assay (Noga 1989), in which $A$. ocellatum's entire life cycle is replicated in vitro using a gill cell line (G1B) as host cells. The DC-1 isolate of $A$. ocellatum was used for all studies. This isolate has been continuously propagated in vitro since 1986 
(Noga 1987) and is still highly pathogenic to fish (U. Silphaduang \& E. Noga unpubl. data). Stocks of G1B cells (ATCC \#CRL 2536, American Type Culture Collection, Manassas, VA) were propagated in a modified Ham's F-12 medium at $25^{\circ} \mathrm{C}$ in $75 \mathrm{~cm}^{2}$ flasks. For experiments, monolayers were gently trypsinized, resuspended in medium, and counted. Cells were then seeded into 96-well tissue culture plates and allowed to grow to confluency. The G1B monolayers were then adapted to an artificial seawater solution (IO2/HBSS).

Infective dinospores were produced from tomonts using standard procedures, and equal numbers of dinospores were inoculated into replicate wells with various antibiotics (all $100 \mu \mathrm{g} \mathrm{ml}^{-1}$ ). The number of differentiated dinospores (i.e. trophonts that developed from dinospores, and tomonts that developed from trophonts) present in each well were counted under phase contrast microscopy after incubation for $48 \mathrm{~h}$ at $25^{\circ} \mathrm{C}$. Values were expressed as a percentage of the sham-treated control (diluent only added). Photographs of selected cultures were made with a Nikon Diaphot inverted phase contrast microscope. As a putative positive control, we used magainin 2 (Sigma Chemical), a peptide antibiotic isolated from aquatic frogs Xenopus laevis, which has antiprotozoal activity (Zasloff 1987). We also examined the activity of purified calf histone H2B (Boerhinger Mannheim).

We have recently shown that the life stage of Amyloodinium ocellatum which is most susceptible to HLP1 is the trophont (Noga et al. 2001). To determine the activity of antibiotics against young versus mature trophonts, anti-trophont activity was assessed by inoculating replicate wells with an equal number of dinospores. After allowing the dinospores to infect the monolayer and subsequently differentiate into trophonts (which typically occurs within $20 \mathrm{~min}$ in this culture system; Noga 1987), the cultures were washed $5 \times$ with IO2/HBSS at either 30 min (young trophonts) or $24 \mathrm{~h}$ (mature trophonts) to remove any freeswimming dinospores, leaving only attached trophonts. Various antibiotic treatments (HSB HLP-1, calf histone $\mathrm{H} 2 \mathrm{~B}$, or magainin 2; all $100 \mu \mathrm{g} \mathrm{ml}^{-1}$ ) were then added. The numbers of visible trophonts and tomonts (i.e. viable parasites which infected the cell culture and grew) were counted after $48 \mathrm{~h}$ at $25^{\circ} \mathrm{C}$. Values were expressed as a percentage of the sham-treated control (HAc diluent only).

In some experiments, we determined the mean time required for the parasites to consume the entire G1B cell monolayer by observing all cultures daily and recording the time (d) for destruction of the entire monolayer (Noga 1989). In a separate experiment, we seeded untreated G1B cultures with various numbers of dinospores $(1,4,8,17$, or 35 dinospores; 4 replicates per treatment) and compared the mean time to consumption of the monolayer by the parasites.

Statistical analyses. For analysis of the effect of various antibiotics on parasite infectivity or the mean time needed for parasites to consume the entire monolayer, Duncan's pairwise test was used (Zar 1996). Data on the effect of trophont age on parasite infectivity were analyzed as a $2 \times 3$ factorial design with 2 treatments (30 min or $24 \mathrm{~h}$; type of antibiotic) (Neter et al. 1990). These 2 types of treatments were compared at $48 \mathrm{~h}$ after adding parasites to the G1B cultures. For each possible combination of all factors tested, the measurement was replicated 3 times (i.e. 3 wells). Since all data were expressed as a percentage of the control (diluent only), arcsine transformation was done to normalize the data (Zar 1996). All analyses were done using PROC GLM in SAS Version 7 (or Version 8) (SAS Institute).

\section{RESULTS}

\section{Antimicrobial activity in mucus versus epidermis}

The mucus collected from the skin of hybrid striped bass appeared to consist of 2 types: a less viscous mucus which was easily removed and a thicker, more viscous mucus which appeared to be secreted after the thinner mucus was removed from the surface of the epidermis. This difference in mucus composition may have been due to the possibility that the initial mucus material was mixed with water on the surface of the fish, making it less viscous. Both thin and thick mucus samples had no cells by microscopic examination, although varioussized spheres (presumably mucus droplets) were seen in both M1N and M2N. In contrast, scrapings of the epidermis yielded abundant amounts of epithelial cells.

Antibacterial activity was detectable in both mucus types, but was much less than the activity detected in the epidermis, especially considering that the epidermis extracts were diluted 4 -fold (Fig. 1). The potency of
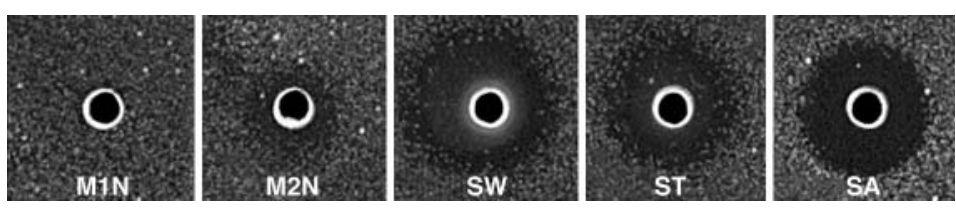

Fig. 1. Comparison of the antibacterial activity of representative hybrid striped bass mucus and epidermis samples using the radial diffusion assay. $\mathrm{M} 1 \mathrm{~N}$ = first neat mucus sample, M2N = second neat mucus sample. Epidermis samples were prepared by extracting in either distilled-deionized water (SW), $50 \mathrm{mM}$ tris buffer $\mathrm{pH} 7.2$ (ST), or $1 \%$ acetic acid (SA). Note that no diluent controls (water, tris, acetic acid) had any activity. The units $\mathrm{ml}^{-1}$ of activity of the samples prepared in this experiment are shown in Table 1 
Table 1. Comparison of the antibacterial activity of hybrid striped bass skin mucus and epidermis samples using the radial diffusion assay. HLP-1 equivalents is the amount of antibacterial activity in the samples expressed in an equivalent concentration of hybrid striped bass HLP-1. Values are the means of 3 replicates from the experiment shown in Fig. 1. Note that no diluent controls (water, tris, acetic acid) had any activity. Replication of this experiment yielded similar results. One unit of activity is equivalent to $10 \mu \mathrm{g} \mathrm{HLP}-1 \mathrm{ml}^{-1}$

\begin{tabular}{|c|c|c|}
\hline Sample & $\begin{array}{l}\text { Units } \mathrm{ml}^{-1} \\
\text { in sample } \\
\quad( \pm \mathrm{SD})\end{array}$ & $\begin{array}{l}\text { HLP-1 } \\
\text { equivalents } \\
\left(\mu \mathrm{g} \mathrm{ml}^{-1}\right)\end{array}$ \\
\hline First neat mucus sample (M1N) & $1 \pm 1$ & 10 \\
\hline Second neat mucus sample (M2N) & $8 \pm 3$ & 80 \\
\hline $\begin{array}{l}\text { Epidermis, distilled } \\
\text { deionized water (SW) }\end{array}$ & $59 \pm 33$ & 590 \\
\hline Epidermis, $50 \mathrm{mM}$ tris & & \\
\hline buffer $\mathrm{pH} 7.2(\mathrm{ST})$ & $36 \pm 21$ & 360 \\
\hline Epidermis, $1 \%$ acetic acid (SA) & $38 \pm 7$ & 380 \\
\hline
\end{tabular}

the activity, as judged by clearing zone diameters, was similar after equal amounts of tissue were extracted with either distilled-deionized water or tris buffer, or after extracting in dilute (1\%) acetic acid and boiling for $5 \mathrm{~min}$ (Fig. 1, Table 1). Epidermis extracts from rainbow trout yielded similar activity (data not shown).

AU-PAGE of the epidermis extracts indicated that there was a band which migrated in a similar fashion to calf histone H2B, suggesting that HLP-1 was present in these samples (Fig. 2) (calf histone H2B migrates similarly to HLP-1 [Noga et al. 2001] and is a commercially

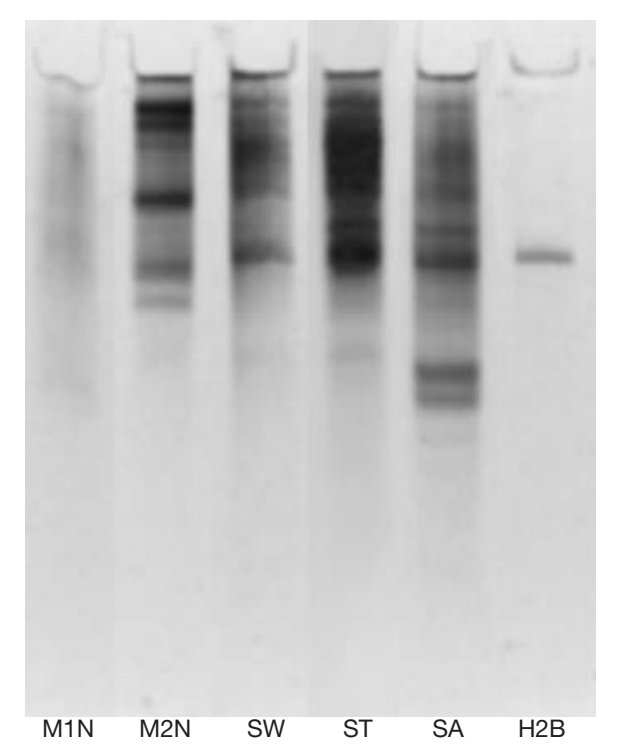

Fig. 2. Acid-urea polyacrylamide gel electrophoresis of hybrid striped bass mucus and epidermis samples. Samples were prepared as described in Fig. 1 using different fish. The gel was stained with Coomassie Blue R-250 available standard). However, this band was not detectable in either M1N or M2N, which corresponded to the almost complete lack of antibacterial activity in both of these samples (Fig. 1). A similar amount of antibacterial activity was identified in whole gill tissue of both hybrid striped bass and rainbow trout, when extracted in either water, tris or acetic acid (data not shown).

\section{Cytological effects of HLPs}

Exposure to all antibiotics had a dramatic effect on Amyloodinium ocellatum trophonts and tomonts. The most striking features were the inhibition of trophont growth and tomont differentiation (Fig. 3). In all 4 antibiotic exposures, some tomonts divided earlier than the controls (reflecting the fact that they formed smaller tomonts). This was most often seen with exposures to RBT HLP-1, where trophonts which survived exposure often formed very small tomonts (i.e. differentiated prematurely), did not divide, and eventually died (Fig. 3f). These changes were also seen to a much lesser extent with exposure to HSB HLP-1; however, some tomonts exposed to HSB HLP-1 became larger than those in control (HAc) cultures (Fig. 3a-d). One subtle feature which often distinguished antibiotictreated cultures from untreated cultures was what appeared to be a less aggressive feeding behavior of treated troponts, as indicated by less damage to G1B cells adjacent to attached trophonts.

One of the most interesting effects was that parasites exposed to any of the 4 antibiotics often continued to grow as apparently normal trophonts, but after forming tomonts would often die prior to or soon after beginning to divide ('delayed mortality') (Fig. 3c,e,g). While exact counts of divided versus undivided parasites would be unreliable due to the dynamic nature of parasite development, it was apparent from our observations that in all antibiotic treatments, there was a higher number of abnormal tomonts compared to the number seen in the control (HAc) cultures. Some tomonts died with shrinkage of the cytoplasmic contents away from the periphery of the cyst wall (Fig. 3e,f). In other cases, tomonts divided very slowly. The percentage of abnormal tomonts appeared to be highest in magainin 2, where many remained undivided or did not complete their division cycles to form dinospores (Fig. 3g,h).

A sublethal effect that may be related to the 'delayed mortality' was prolongation of the life cycle (i.e. a slowing of the parasite's growth rate) (Table 2). This was initially suggested by the lack of correlation between the number of initially surviving trophonts and the time required for these parasites to feed on and con- 


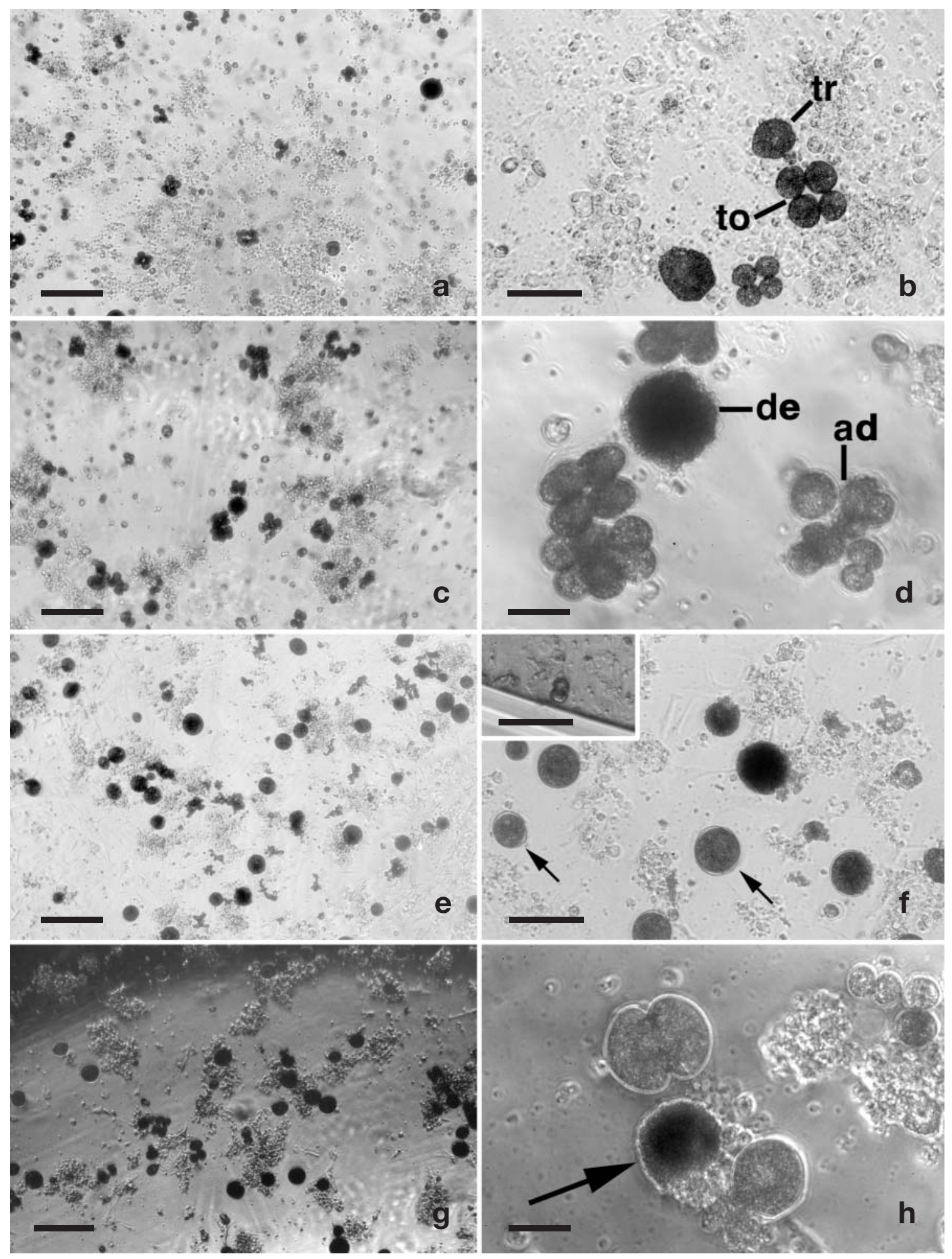

Fig. 3. Amyloodinium ocellatum. Effect of HLP-1 $\left(100 \mu \mathrm{g} \mathrm{ml}^{-1}\right)$ on trophonts and tomonts. Also noted is the age of the culture (i.e. days after inoculating with dinospores). (a) Control (HAc) culture with normal, viable, parasites, including tomonts in various stages of division; Day 14; scale bar $=50 \mu \mathrm{m}$. (b) HAc culture with normal, viable, trophonts (tr) and tomonts (to); Day 39; scale bar $=25 \mu \mathrm{m}$. (c) Culture treated with hybrid striped bass HLP-1 (HSB HLP-1); note the slightly greater number of undivided tomonts, most of which are dead (failed to divide after $30 \mathrm{~d}$ ); Day 14; scale bar $=50 \mu \mathrm{m}$. (d) Culture treated with HSB HLP-1; note the dead (de), asynchronously dividing (ad) tomonts; Day 14; scale bar $=10 \mu \mathrm{m}$. (e) Culture treated with rainbow trout HLP-1 (RBT HLP-1); note the many undivided tomonts, most of which are dead (failed to divide after $30 \mathrm{~d}$ ); Day 14 ; scale bar $=50 \mu \mathrm{m}$. (f) Culture treated with RBT HLP-1; note the dead tomonts, as indicated by the cytoplasm contracted away from the cell wall (arrows) (Noga 1989); Day 14; scale bar $=25 \mu \mathrm{m}$. Inset: a different culture treated with RBT HLP-1; note the very small 2-cell tomont; this parasite failed to divide further; Day 5; scale bar $=25 \mu \mathrm{m}$. (g) Culture treated with magainin 2; note the many undivided tomonts, most of which are dead (failed to divide after $30 \mathrm{~d}$ ); Day 14; scale bar $=50 \mu \mathrm{m}$. (h) Culture treated with magainin 2; tomonts will not divide further; note the irregular cell wall of the dark, dead tomont (arrow); Day 14; scale bar $=10 \mu \mathrm{m}$ 
Table 2. Amyloodinium ocellatum. Effect of polypeptide antibiotics $\left(100 \mu \mathrm{g} \mathrm{ml}^{-1}\right)$ on infectivity versus long-term survival in vitro. All values presented are the mean \pm SE of 3 replications. Values in the same column with different letter superscripts are significantly different $(p<0.01)$. NA: cultures appeared to have no viable parasites after $4 \mathrm{~d}$

\begin{tabular}{|lccc|}
\hline Treatment & $\begin{array}{c}\text { Initial percent } \\
\text { infectivity } \\
\text { (\% of HAc } \\
\text { control) }\end{array}$ & $\begin{array}{c}\text { Mean time } \\
\text { to monolayer } \\
\text { destruction } \\
(\mathrm{d})\end{array}$ & $\begin{array}{c}\text { Percent increase } \\
\text { in time to mono- } \\
\text { layer consumption } \\
\text { (\% of HAc control) }\end{array}$ \\
\hline HAc only & $100.0 \pm 4.1^{\mathrm{a}}$ & $16.0 \pm 1.5^{\mathrm{a}}$ & - \\
Magainin 2 & $42.0 \pm 4.1^{\mathrm{b}}$ & $61.3 \pm 3.0^{\mathrm{b}}$ & 283 \\
Hybrid striped bass HLP-1 & $20.5 \pm 0.0^{\mathrm{c}}$ & $22.7 \pm 0.5^{\mathrm{a}}$ & 42 \\
Calf histone H2B & $12.6 \pm 3.2^{\mathrm{c}, \mathrm{d}}$ & $33.7 \pm 0.2^{\mathrm{c}}$ & 106 \\
Rainbow trout HLP-1 & $5.8 \pm 1.1^{\mathrm{d}}$ & NA & NA \\
\hline
\end{tabular}

that fish skin mucus was lethal to the monogenean worm Epibdella mellenia. Moore et al. (1994) found biologically active factors against another monogenean, Gyrodactylus stellatus, in the mucus of infected juvenile English sole Pleuronectes vetulus. Harrell et al. (1976) observed that skin secretions from rainbow trout were inhibitory to Vibrio (Listonella) anguillarum. Austin \& McIntosh (1988) identified an antibacterial activity that resembled a glycoprotein in the skin and eye mucus of rainbow trout. Magarinos et al. (1995) also detected activity against Passume/destroy the entire G1B cell monolayer. This was most apparent when comparing the growth of parasites exposed to magainin 2 compared to other antibiotics. While magainin 2 typically had the least effect on parasite infectivity of any antibiotic, it caused a much greater delay in monolayer destruction than either calf histone H2B or HSB HLP-1 (Table 2). In a separate experiment, when different numbers of dinospores were seeded into separate, untreated G1B cultures, all cultures had a similar time to destruction of the monolayer $(\mathrm{p}<0.05)$, suggesting that initial parasite density is not a significant influence on mean time to monolayer consumption and thus parasite growth. This supports our observations that the antibiotics appear to be slowing parasite growth directly, rather than indirectly, due to causing a smaller number of initially surviving parasites.

\section{Effect of antibiotics on young versus mature trophonts}

While both HSB HLP-1 and magainin 2 were significantly inhibitory to Amyloodinium ocellatum trophont survival ( $p<0.01)$, there was no significant difference in the susceptibility of young (30 min) versus mature $(24 \mathrm{~h})$ trophonts to either antibiotic. Activity against young versus mature trophonts was similar for HSB HLP-1 (59.1 \pm 10.3 vs $63.5 \pm 5.0 \%$ infectivity, p > 0.05) and magainin $2(73.6 \pm 9.0$ vs $67.0 \pm 10.7 \%$ infectivity, $\mathrm{p}>0.05)$.

\section{DISCUSSION}

Previous investigators have detected antimicrobial activity in skin extracts from various fish, although whether these activities were due to specific or innate defenses was not always clear. Nigrelli (1935) found teurella piscicida (= Photobacterium damsela subsp. piscicida) in turbot Scophthalmus maximus skin mucus. Videler et al. (1999) identified and partially sequenced a $21 \mathrm{kDa}$ glycoprotein in the mucus envelope of the queen parrotfish Scarus vetula which was associated with antibacterial activity. Wood et al. (1988) found that skin mucus from brown trout Salmo trutta killed the spores of water molds in the Saprolegnia diclina-parasitica complex. While at least some of the above activities might be attributed to complement cytotoxic antibodies or even microbial products (Westerdahl et al. 1991), it is likely that at least part of the activity observed is due to endogenous polypeptide antibiotics, such as HLPs.

Some prior studies have failed to observe antimicrobial activity in fish skin secretions (Hattingh \& Van Warmelo 1975, Willoughby \& Pickering 1977). CrouseEisnor et al. (1985) found no anti-Aeromonas actvity in mucus extracts from goldfish Carassius auratus. Subbacterial activity in the skin or buccal mucus of the maternal mouth-brooding cichlid Oreochromis mossambicus, at any stage of their breeding cycle. However, the sensitivity of the detection techniques used in the above studies, combined with the very weak activity often present in mucus (Fig. 1; Landsberg et al. 1992) compared to epithelium, suggests that activity might have gone undetected.

We have previously demonstrated that the skin mucus of tilapia Oreochromis aureus has anti-Amyloodinium ocellatum activity when measured by our standard cell culture infectivity assay (Landsberg et al. 1992); however, this activity is relatively weak, requiring at least an $80 \%$ mucus concentration to be inhibitory. Being a cell culture assay, the infectivity assay requires sterile samples which are not easily prepared from crude skin extracts. Thus, because HLPs have broad-spectrum activity against both prokaryotes and eukaryotes (Robinette et al. 1998, Noga et al. asinghe \& Sommerville (1988) did not find any anti- 
2001), in the current study, we compared the relative antibiotic activity of the skin compartments using an antibacterial assay, because this assay provides a more quantitative and sensitive measure of total antibiotic activity.

The skin of virtually all fish species is not keratinized but rather consists entirely of living cells. Thus, when collecting mucus, epidermal cells can be easily and inadvertently removed. This is especially true if any abrasive means are used which traumatize the skin and cause epidermal cell exfoliation. When collecting the epidermis, one cannot totally separate the activity present in the mucus from that in the epidermis because the mucus-producing (goblet) cells reside in the epidermis. However, our present data and the previously documented weak anti-Amyloodinium ocellatum activity in fish mucus (Landsberg et al. 1992) suggest that the most potent component of the HLP host defense is in the epidermis and this is where potential pathogens would be most inhibited by these antibiotics. Specific measurement of HLP-1 levels in the mucus and epidermis of hybrid striped bass skin also supports these data; HLP-1 levels via enzyme-linked immunsorbent assay have shown that levels in epidermis extracts are much higher (14 to 52 ELISA Units $\mathrm{ml}^{-1}$ ) compared to those in either M1N or M2N, which are both undetectable (H. Callahan, U. Silphaduang \& E. Noga unpubl. data). The amount of antibiotic activity in the epidermis (Table 1) is more than enough to kill A. ocellatum. The infectivity of $A$. ocellatum is reduced by as little as $12.5 \mu \mathrm{g}$ HLP- $1 \mathrm{ml}^{-1}$ (Noga et al. 2001). Since the epidermis contains not only epithelial (malpighian) cells but also goblet cells and various immune cells (lymphocytes, mast cells, Langerhans cells), further studies are needed to confirm the specific cellular source of the HLPs.

These data also suggest that HLPs may function in mainly protecting against the most aggressive types of ectoparasites. Amyloodinium ocellatum infects skin and gill epithelial cells, penetrating these cells as it feeds (Noga 1987), and thus would be in intimate contact with antiparasitic substances released by these cells. Other highly lethal protozoan ectoparasites also penetrate the host epithelium, including the kinetoplastid flagellate Ichthyobodo necator, and the ciliates Ichthyophthirius multifiliis and Cryptocaryon irritans. Because of their highly invasive nature, these agents are among the most important parasites affecting fish (Woo 1995). Other ectoparasites, which only reside on the surface of the epithelium in the mucus layer (e.g. Trichodina, Chilodonella), might be less susceptible to the action of HLPs.

We provide further evidence here that HLPs are important defensive molecules in fish by the fact that the relatively mild extraction techniques which we use to obtain HLPs from fish tissues are not strong enough to release histone bound to nucleic acid (Moehs et al. 1992). Also, the activity is just as strong when we extract tissues in water (Table 1, Fig. 1). These results are similar to those which we have found when isolating HLPs from channel catfish (Robinette et al. 1998). Thus, the polypeptides which we are isolating are free within the cell and/or extracellular space, as has been demonstrated for histone $\mathrm{H} 1$ in human epidermis (Kashima 1991).

Only recently have histones or histone-like polypeptides been reported to be defensive molecules in fish (Robinette et al. 1998, Noga et al. 2001). Park et al. (1998) recently found that experimental trauma to an Asian catfish (Parasilurus asotus) induced the release of a potent antimicrobial peptide, parasin I, which was highly homologous to the N-terminal portion of histone H2A. Richards et al. (2001) identified histone H1 in the liver, intestine and stomach of Atlantic salmon Salmo salar which was inhibitory to Escherichia coli. Patrzykat et al. (2001) found that fragments of histone H1 isolated from the mucus and blood of coho salmon Oncorhynchus kisutch, while not having significant antibacterial activity, synergized the antibacterial activity of lysozyme as well as pleurocidin, an antimicrobial peptide from winter flounder Pleuronectes americanus. Also, previous research suggests that histones or histone-like molecules may play an important role in the defense of other vertebrates, including humans (see Robinette et al. 1998 for a review). For example, Rose et al. (1998) found that human histone H1 may play a role in protecting against bacterial pathogens in the intestinal mucosa.

Recently, other types of novel polypeptide antibiotics have been isolated from the skin of fish (see Lauth et al. 2002 for a review). However, to date, HLPs are the only polypeptide antibiotics from fish which have been shown to be antiparasitic and to have a very broad host distribution, being isolated from the skin and gill of several unrelated fish species, including channel catfish, rainbow trout and hybrid striped bass (Robinette et al. 1998, Noga et al. 2001). However, because polypeptide antibiotics often have activity against eukaryotic pathogens as well, some of these other agents might also have antiparasitic activity.

All antibiotics which we tested had dramatic cytological effects on Amyloodinium ocellatum trophonts and tomonts (Fig. 3), which supports our prior observations that the trophont is the main target of these agents (Noga et al. 2001). This is in contrast to therapeutics such as copper and formalin, which target the dinospore (Noga \& Levy 1995). The preferential effect on trophonts rather than dinospores (Noga et al. 2001) is also consistent with the highest concentration of HLPs being in the epidermis rather than the mucus. 
Interestingly, there was no difference in the susceptibility of young versus mature trophonts to either HLP1 or magainin 2 (Table 2). While we suspected that older trophonts might be more resistant, due to their larger size and presumably more developed defenses (e.g. thicker cell wall, etc.), age (or size) apparently does not provide any added protection from damage. This implies that route of exposure to the antibiotics might be similar for young and mature trophonts and may relate to their intimate relationship to the host.

One of the most interesting effects we observed was that parasites exposed to any of the antibiotics often continued to grow apparently normally, but after forming tomonts would often die prior to or soon after beginning to divide (Fig. 3). This occurred to some degree with all 4 antibiotic treatments. These data suggest that exposure to these antibiotics had a long-term effect on parasite growth and survival. This 'delayed mortality' is supported by our previous observations of a progressive decrease in parasite numbers from 48 to $96 \mathrm{~h}$ after treatment, indicating that parasites were dying long after the initial exposure to the antibiotics (Noga et al. 2001). In addition, antibiotic-treated parasites required a much longer time to reproduce enough so that they could consume the entire G1B cell monolayer (Table 2). This did not appear to be due to the initially lower numbers of trophonts present in antibiotictreated cultures, since untreated cultures seeded with different numbers of parasites had a similar time to destruction of the monolayer. While one might intuitively expect that G1B cultures with fewer parasites would not consume the monolayer as quickly, we have observed that when cultures are seeded with parasites in the density range which we have tested, cultures with the higher numbers of parasites produce slightly smaller trophonts. This would tend to 'even out' any initial differences in reproductive rate since smaller trophonts produce fewer dinospores. It also supports our conclusion that the antibiotic-treated cultures are growth-impaired. The mechanism responsible for delayed mortality is not known. However, it is unlikely to be due to the presence of residual antibiotic in the cultures because the effect continued to be observed several days to weeks after initial exposure to the antibiotics. These small polypeptides would not be expected to be stable for such a long time under our experimental conditions.

Delayed mortality and impaired growth have important implications for parasite survival because they imply that HLP-1 may adversely affect Amyloodinium ocellatum even after it has left the host, which would certainly be advantageous from the standpoint of the host. This modulation of parasite development might also relate to how $A$. ocellatum may maintain a latent or carrier state on clinically normal fish. Both we and others (Lawler 1980, Noga \& Levy 1995, E. Noga unpubl. data) have observed A. ocellatum on clinically normal fish during routine health screens. Why these parasites are inhibited from multiplying is unclear, but we have recently found that HLP-1 levels are significantly depressed in the skin of fish exposed to chronic stress (Robinette \& Noga 2001). This suggests that chronic stress might increase the risk of fish developing amyloodiniosis and that HLP-1 might play a role in maintaining the carrier state. Clearly, this interdependent host-pathogen relationship requires further study and may be applicable to other host-parasite relationships.

Acknowledgements. We thank X. He for assistance with statistical analysis, D. Jennings (Jennings Trout Farm, Canton, $\mathrm{NC}$, USA) for supplying rainbow trout and L. Brothers (Carolina Fisheries, Aurora, NC, USA) for supplying hybrid striped bass. This work was supported by Research Grant No. US-3030-98 from BARD, the United States-Israel Binational Agricultural Research and Development Fund, Grant No. NA46RG0087 from the National Sea Grant College Program, National Oceanic and Atmospheric Administration, to the North Carolina Sea Grant College Program, and from the USDA-NRI Competitive Grant Program (Project \#97-352047722) to E.J.N.

\section{LITERATURE CITED}

Austin B, McIntosh D (1988) Natural antibacterial compounds on the surface of rainbow trout, Salmo gairdneri Richardson. J Fish Dis 11:275-277

Cobb CS, Levy MG, Noga EJ (1998) Development of immunity by the tomato clownfish (Amphiprion frenatus) to the dinoflagellate parasite Amyloodinium ocellatum. J Aquat Anim Health 10:259-263

Crouse-Eisnor RA, Cone DK, Odense PH (1985) Studies on relations of bacteria with skin surface of Carassius auratus L. and Poecilia reticulata. J Fish Biol 27:395-402

Harrell LW, Ettlinger HM, Hodgins HO (1976) Humoral factors important in resistance of salmonid fish to bacterial disease. II. Anti-Vibrio anguillarum activity in mucus and observations on complement. Aquaculture 1:363-370

Harwig SL, Chen NP, Park ASK, Lehrer RI (1993) Purification of cysteine-rich bioactive peptides from leukocytes by continuous acid-urea-polyacrylamide gel electrophoresis. Anal Biochem 208:382-386

Hattingh J, Van Warmelo KT (1975) The cuticular layer of the skin of certain cyprinidae. Zool Afr 10:102-103

Kashima M (1981) H1 histones contribute to candidacidal activities of human epidermal extract. J Dermatol 18: 695-706

Laemmli U (1970) Cleavage of structural proteins during the assembly of the head of bacteriophage T4. Nature 227: $680-685$

Landsberg JH, Smith SA, Noga EJ, Richards SA (1992) Effect of serum and mucus of blue tilapia, Oreochromis aureus on infectivity of the parasitic dinoflagellate, Amyloodinium ocellatum in cell culture. Fish Pathol 27:163-169

Lauth X, Shike H, Burns JC, Westerman ME and 7 others (2002) Discovery and characterization of two isoforms of moronecidin, a novel antimicrobial peptide from hybrid striped bass. J Biol Chem 277:5030-5039. 
Lawler AR (1980) Studies on Amyloodinium ocellatum (Dinoflagellata) in Mississippi Sound: natural and experimental hosts. Gulf Res Rep 6:403-413

Magarinos B, Pazos F, Santos Y, Romalde JL, Toranzo AE (1995) Response of Pasteurella piscicida and Flexibacter marinus to skin mucus of marine fish. Dis Aquat Org 21:103-108

Mitta G, Hubert F, Dyrynda EA, Boudry P, Roch P (2000) Mytilin B and MGD2, two antimicrobial peptides of marine mussels: gene structure and expression analysis. Dev Comp Immunol 24:381-393

Moehs CP, Baxevanis AD, Moudrianakis EN, Spiker S (1992) Enhanced stability of histone octamers from plant nucleosomes: role of H2A and H2B histones. Biochemistry 31: 10844-10851

Moore MM, Kaattari SL, Olson RE (1994) Biologically active factors against the monogenetic trematode Gyrodactylus stellatus in the serum and mucus of infected juvenile English soles. J Aquat Anim Health 6:93-100

Neter JW, Wasserman W, Kutner MH (1990) Applied linear statistical models, 3rd edn. Richard D. Irwin, Homewood, IL

Nigrelli RF (1935) On the effect of fish mucus on Epibdella mellenia monogenetic trematode of marine fishes. J Parasitol 21:438 (Abstract)

Noga EJ (1987) Propagation in cell culture of the dinoflagellate Amyloodinium, an ectoparasite of marine fishes. Science 236:1302-1304

Noga EJ (1989) Culture conditions affecting the in vitro propagation of Amyloodinium ocellatum. Dis Aquat Org 6: 137-143

Noga EJ, Levy MG (1995) Dinoflagellate parasites of fish. In: Woo PTK (ed) Fish diseases. I: Protozoan and metazoan infections. CAB International, Oxford, p 1-25

Noga EJ, Fan Z, Silphaduang U (2001) Histone-like proteins from fish are lethal to the parasitic dinoflagellate Amyloodinium ocellatum. Parasitology 123:57-65

Oestmann DJ, Lewis DH (1996) Improved cell culture propagation of Amyloodinium ocellatum. Dis Aquat Org 24: 173-178

Park IY, Park CB, Kim MS, Kim SC (1998) Parasin I, an antimicrobial peptide derived from histone H2A in the catfish, Parasilurus asotus. FEBS Lett 437:258-262

Patrzykat A, Zhang L, Mendoza V, Iwama GK, Hancock REW (2001) Synergy of histone-derived peptides of coho salmon with lysozyme and flounder pleurocidin. Antimicrob Agents Chemother 45:1337-1342

Richards RC, O'Neil DB, Thibault P, Ewart KV (2001) Histone H1: an antimicrobial protein of Atlantic salmon (Salmo

Editorial responsibility: Donald Evans,

Athens, Georgia, USA salar). Biochem Biophys Res Comm 284:549-555

Robinette DR, Noga EJ (2001) Histone-like protein (HLP): a novel method for assessing chronic stress in fish. Dis Aquat Org 44:97-107

Robinette DR, Wada S, Arroll T, Levy MG, Miller W, Noga EJ (1998) Antimicrobial activity in the skin of the channel catfish Ictalurus punctatus: characterization of broadspectrum histone-like antimicrobial proteins. Cell Mol Life Sci 54:467-475

Rose FR, Bailey K, Keyte JW, Chan WC, Greenwood D, Mahida YR (1998) Potential role of epithelial cell-derived histone $\mathrm{H} 1$ proteins in innate antimicrobial defense in the human gastrointestinal tract. Infect Immun 66:3255-3263

Schroder JM (1999) Epithelial peptide antibiotics. Biochem Pharmacol 57:121-134

Smith SA, Noga EJ, Levy MG, Gerig TM (1993) Effect of serum from tilapia Oreochromis aureus, immunized with dinospores of Amyloodinium ocellatum, on the motility, infectivity and growth of the parasite in cell culture. Dis Aquat Org 15:73-80

Subasinghe RP, Sommerville C (1988) No antibacterial properties found in buccal and skin mucus of the mouth-brooding cichlid Oreochromis mossambicus. Asian Fish Sci 2:109-113

Tossi A, Sandri L, Giangaspero A (2000) Amphipathic, alphahelical antimicrobial peptides. Biopolymers 55:4-30

Videler V, Geertjes GJ, Videler JJ (1999) Biochemical characteristics and antibiotic properties of the mucus envelope of the queen parrotfish. J Fish Biol 54:1124-1127

Westerdahl A, Christer Olsson J, Kjelleberg S, Conway PL (1991) Isolation and characterization of turbot (Scophtalmus maximus). Appl Environ Microbiol 57:2223-2228

Willoughby LG, Pickering AD (1977) Viable Saprolegniaceae spores on the epidermis of salmonid fish Salmo trutta and Salvelinus alpinus. Trans Br Mycol Soc 68:91-95

Woo PTK (1995) Fish diseases. I: Protozoan and metazoan infections. CAB International, Oxford

Wood SE, Willoughby LG, Beakes GW (1988) Experimental studies on uptake and interaction of spores of the Saprolegnia diclina-parasitica complex with external mucus of browm trout (Salmo trutta). Trans Br Mycol Soc 90:63-73

Zar JH (1996) Biostatistical analysis, 3rd edn. Prentice Hall, Upper Saddle River, NJ

Zasloff M (1987) Magainins, a class of antimicrobial peptides from Xenopus skin: isolation, characterization of two active forms, and partial cDNA sequence of a precursor. Proc Natl Acad Sci USA 84:5449-5453

Zasloff M (2002) Antimicrobial peptides of multicellular organisms. Nature 415:389-395

Submitted: November 26, 2001; Accepted: July 15, 2002 Proofs received from author(s): December 2, 2002 